\section{Alkaline-based curcumin extraction from selected zingiberaceae for antimicrobial and antioxidant activities}

By: Othman, R (Othman, Rashidi) ${ }^{[1]}$; Abdurasid, MA (Abdurasid, Mohd Akram) $)^{[1]}$; Mahmad, N (Mahmad, Noraini) ${ }^{[1]}$; Fadzillah, NA (Fadzillah, Nurrulhidayah Ahmad) ${ }^{[1]}$

View Web of Science ResearcherID and ORCID

\section{PIGMENT \& RESIN TECHNOLOGY}

Volume: 48 Issue: 4 Pages: 293-300

DOI: $10.1108 /$ PRT-08-2018-0071

Published: JUL 12019

Document Type: Article

View Journal Impact

\section{Abstract}

Purpose The purpose of this paper is to extract, characterise and quantify curcumin from selected Zingiberaceae of kunyit or turmeric (Curcuma longa), temu lawak or Javanese turmeric (Curcuma xanthorrhiza), temu pauh (Curcuma mangga), lempoyang (Zingiber zerumbet) and bonglai (Zingiber cassumunar) using alkaline and chemical-based extraction method for antimicrobial and antioxidant activities.

Design/methodology/approach Through the alkaline-based extraction method, all parts of rhizome samples were freeze-dried for $72 \mathrm{~h}$ before grounded into a fine powder and kept at -20 degrees $\mathrm{C}$. The powdered sample $(0.1 \mathrm{~g})$ was weighed and placed in a $50 \mathrm{~mL}$ tube. About $20 \mathrm{~mL}$ of $2 \mathrm{M} \mathrm{NaOH}$ solution was added into the tube. The solution was allowed to stand for $30 \mathrm{~min}$. Then, $20 \mathrm{~mL}$ of ethyl acetate was added into the tube. The solution was mixed well then centrifuged at $13,500 \mathrm{rpm}$ for $3 \mathrm{~min}$. The upper layer was collected using a pipette. The process was repeated until the upper layer became almost colourless. The collected ethyl acetate solution was concentrated using a rotary evaporator to remove the ethyl acetate from the extracted compound. The concentrated curcumin was placed in a universal bottle, which was then dried from the remaining ethyl acetate using nitrogen drying process. The dried curcumin was then stored inside the freezer at $-20 \mathrm{oC}$. The antimicrobial activities were using agar diffusion method against bacterial and fungi, while the antioxidant activity was evaluated using 2,2-diphenyl-1-picrylhydrazyl (DPPH) scavenging assay.

Findings All the samples successfully showed a single peak (curcumin) that gained from the high-performance liquid chromatography (HPLC) chromatogram analysis (at $425 \mathrm{~nm}$ ) using the alkaline-based extraction method and the highest curcumin content was in turmeric (12.951.07mg/g DW). At $10.0 \mathrm{mg} / \mathrm{mL}$ curcumin concentration, the best antibacterial activity was against on methicillin-resistant staphylococcus aureus (MRSA) with $7.50+/$ $0.71 \mathrm{~mm}$ inhibition zone, while the best antifungal activity was against on Aspergillus niger with $8.00+/-0.41 \mathrm{~mm}$ inhibition zone. The DPPH antioxidant test resulted in the highest inhibition (110.41 per cent) was at $0.25 \mathrm{mg} / \mathrm{mL}$ curcumin concentration.

Originality/value Through HPLC analysis, all samples successfully showed a single peak of curcumin at $425 \mathrm{~nm}$. The total carotenoid determination from turmeric revealed that the samples content was substantially higher using alkaline-based extraction $(18.40+/-0.07 \mathrm{mg} / \mathrm{g}$ DW) compared to chemical-based extraction $(9.42+/-0.20 \mathrm{mg} / \mathrm{g}+/-\mathrm{SD})$.

\section{Keywords}

Author Keywords: Antioxidants; Colorant; Pigments; Pharmaceuticals industry; Antimicrobial; HPLC; Alkaline-based extraction; Turmeric; Zingiberaceae KeyWords Plus: STABILITY

\section{Author Information}

Reprint Address: Othman, $\mathrm{R}$ (reprint author)

+ Int Islamic Univ Malaysia, KAED, Int Inst Halal Res \& Training, Kuala Lumpur, Malaysia.

Addresses:

+ [1] Int Islamic Univ Malaysia, KAED, Int Inst Halal Res \& Training, Kuala Lumpur, Malaysia

E-mail Addresses: rashidi@iium.edu.my; akramabdulrasid@gmail.com; norainimahmad@gmail.com; nurrulhidayah@iium.edu.my

Funding

\begin{tabular}{|c|c|c|}
\hline Funding Agency & Show details & Grant Number \\
\hline \multicolumn{3}{|c|}{ Ministry of Higher Education \& Scientific Research (MHESR) } \\
\hline IIUM & & PRIGS18-001-0001 \\
\hline
\end{tabular}

View funding text

Publisher

EMERALD GROUP PUBLISHING LTD, HOWARD HOUSE, WAGON LANE, BINGLEY BD16 1WA, W YORKSHIRE, ENGLAND

\section{Journal Information}

Impact Factor: Journal Citation Reports

Categories / Classification

\section{Citation Network}

In Web of Science Core Collection

0

Times Cited

Create Citation Alert

20

Cited References

View Related Records

Use in Web of Science

Web of Science Usage Count

6 8

Last 180 Days $\quad$ Since 2013

Learn more

This record is from:

Web of Science Core Collection

- Science Citation Index Expanded

Suggest a correction

If you would like to improve the quality of the data in this record, please suggest a correction. 


\section{Cited References: 20}

5. Curcumin, a major constituent of turmeric, corrects cystic fibrosis defects

6. Carotene content of some common (cereals, pulses, vegetables, spices and condiments) and unconventional sources of plant origin

7. POTENTIAL ANTICANCER ACTIVITY OF TURMERIC (CURCUMA-LONGA) 
15. Determination of natural carotenoid pigments from freshwater green algae as potential halal food colorants

By: Othman, R.; Noh, N.; Nurrulhidayah, A. F.; et al.

INTERNATIONAL FOOD RESEARCH JOURNAL Volume: 24 Supplement: S Pages: S468-S471 Published: DEC 2017

16. Natural carotenoid pigments of 6 chlorophyta freshwater green algae species.

Times Cited: 1

By: Othman, R.; Noh, N. H.; Hatta, F. A. M.; et al.

Journal of Pharmacy and Nutrition Sciences Volume: 8 Issue: 1 Pages: 1-5 Published: 2018

17. Methods for total antioxidant activity determination: a review

Times Cited: 86

By: Pisoschi, A.M.; Negulescu, G.P.

Biochem. Anal. Biochem. Volume: 1 Pages: 1-10 Published: 2011

18. ANTITUMOR AND ANTIOXIDANT ACTIVITY OF NATURAL CURCUMINOIDS

Times Cited: 721

By: RUBY, AJ; KUTTAN, G; BABU, KD; et al.

CANCER LETTERS Volume: 94 Issue: 1 Pages: 79-83 Published: JUL 201995

19. STUDIES ON CURCUMIN AND CURCUMINOIDS .8. PHOTOCHEMICAL STABILITY OF CURCUMIN

Times Cited: 159

By: TONNESEN, HH; KARLSEN, J; VANHENEGOUWEN, GB

ZEITSCHRIFT FUR LEBENSMITTEL-UNTERSUCHUNG UND-FORSCHUNG Volume: 183 Issue: 2 Pages: 116-122 Published: AUG 1986

20. YIELD AND CURCUMIN CONTENT STABILITY OF FIVE UB CLONES OF TEMULAWAK (Curcuma xanthorriza Rox.)

Times Cited: 1

By: Wardiyati, Tatik; Kuswanto; Azizah, Nur

AGRIVITA Volume: 34 Issue: 3 Pages: 233-238 Published:OCT 2012

Showing $\mathbf{2 0}$ of $\mathbf{2 0}$ View All in Cited References page 